\title{
PENGARUH PEMANFAATAN MEDIA PEMBELAJARAN AUDIOVISUAL DALAM UPAYA PENINGKATAN MOTIVASI BELAJAR DAN ADVERSITY QUOTIENT TERHADAP PRESTASI BELAJAR MATEMATIKA (Studi Kasus : SMK Rosma Karawang)
}

\author{
Rini Malfiany \\ Sekolah Tinggi Manajemen Informatika dan Komputer LIKMI \\ Jl. Ir. H. Juanda Bandung 40132 \\ rini.malfiany@gmail.com
}

\begin{abstract}
ABSTRAK
Tujuan penelitian ini untuk mengetahui : 1). Pengaruh penggunaan media Pembelajaran Audiovisual terhadap prestasi belajar. 2). Pengaruh motivasi belajar terhadap prestasi belajar. 3). Pengaruh adversity quotient terhadap prestasi belajar. Penelitian ini dilaksanakan di SMK Rosma Karawang sebagai kelas eksperimen yaitu Kelas X TKJ, dan Kelas X AP sebagai kelas pembanding. Metode penelitian ini menggunakan metode eksperimen. Penarikan sampel penelitian adalah multi stage random sampling. Teknik pengumpulan data menggunakan nilai dan angket. Nilai dan angket untuk mengetahui motivasi belajar siswa dan adversity quotient siswa. Instrumen diujikan pada Kelas X TKJ dan Kelas X AP SMK Rosma Karawang. Uji validitas dan reliabilitas menggunakan SPSS ver 16.0. dengan 20 butir pertanyaan.

Hasil uji reliabilitas menunjukkan bahwa seluruh variabel koefisien alpha $>0.06$, sehingga seluruh pertanyaan dalam setiap variabel adalah reliabel. Kesimpulan berdasarkan analisis data adalah: 1) Ada pengaruh signifikan pemanfaatan media audiovisual terhadap prestasi belajar mata pelajaran matematika dengan nilai $\mathrm{P} * * *$ taraf signifikasi $5 \%$ artinya $\mathrm{H}_{0}$ ditolak. 2) Tidak ada pengaruh signifikan motivasi belajar terhadap prestasi belajar taraf signifikasi $5 \%$ artinya $\mathrm{H}_{0}$ diterima, tetapi pada taraf signifikan $1 \% \mathrm{H}_{0}$ ditolak. 3) Tidak ada pengaruh signifikan adversity quotient terhadap prestasi belajar pada mata pelajaran matematika pada taraf signifikan $5 \%$ sehingga $\mathrm{H}_{0}$ diterima.
\end{abstract}

Kata Kunci: Pemanfaatan Media Pembelajaran Audiovisual, Motivasi dan Adversity Quotient

\section{PENDAHULUAN}

Seorang guru perlu menyadari bahwa proses komunikasi tidak selalu berjalan lancar, bahkan proses komunikasi dapat menimbulkan kebingungan, salah pengertian bahkan menimbulkan salah konsep. Untuk mengatasi kesulitan tersebut, perlu adanya media pembelajaran sebagai bentuk penyederhanaan atau pemodelan dari konsep-konsep yang abstrak, sehingga konsep yang disajikan lebih nyata dan dapat teramati.

Media komputer merupakan suatu media yang dapat digunakan untuk mengevaluasi materi atau konsep yang abstrak. Penggunaan Multimedia (audio visual) dapat menampilkan tidak hanya grafik, tetapi juga tampilan gambar, suara animasi, video dan teks materi pelajaran, yang dapat mewakili permasalahan matematika yang abstrak. 
Untuk mencapai peningkatan prestasi belajar tersebut guru dituntut menggunakan berbagai cara dalam pembelajaran, salah satunya adalah penggunaan media pembelajaran. Media pembelajaran saat ini yang dirasa menarik bagi peserta didik adalah dengan menggunakan media audiovisual, penggunaan audiovisual yang melibatkan indra paling banyak dibandingkan dengan alat peraga lainnya, dengan audiovisual peserta didik dapat melihat, mendengar. Pemerolehan hasil belajar melalui indera pandang berkisar $75 \%$, melalui indera dengar 13\%, dan melalui indera lainnya sekitar $12 \%$.

Penggunaan media pembelajaran audiovisual diharapkan memberikan motivasi terhadap peserta didik untuk lebih tertarik terhadap pelajaran yang akan disampaikan, penggunaan audiovisual menimbulkan kegairahan peserta didik selama penggunaannya tepat dan sesuai dengan topik yang disampaikan. Dengan adanya motivasi kemungkinan prestasi peserta didik akan meningkat.

Selain motivasi, keberhasilan siswa dalam proses belajar mengajar tergantung bagaimana siswa tersebut mampu bersikap konsisten. Siswa yang konsisten maka ia akan mampu menyelaraskan antara sikap dan perilakunya sampai pada tujuan yang diharapkan tercapai. Adversity quotient merupakan kecerdasan individu dalam mengatasi setiap kesulitan yang muncul. Adversity quotient sering diindentikkan dengan daya juang untuk melawan kesulitan. Adversity quotient dianggap sangat mendukung keberhasilan siswa dalam meningkatkan prestasi belajar.

Berangkat dari gambaran kondisi nyata di atas penulis tertarik mengadakan penelitian tentang PENGARUH PEMANFAATAN MEDIA PEMBELAJARAN AUDIOVISUAL DALAM UPAYA PENINGKATAN MOTIVASI BELAJAR DAN ADVERSITY QUOTIENT TERHADAP PRESTASI BELAJAR MATA PELAJARAN MATEMATIKA.

\section{METODOLOGI PENELITIAN}

Tempat yang digunakan untuk melakukan penelitian adalah SMK Rosma di Karawang tahun pelajaran 2013/2014.

Deskripsi variabel bertujuan untuk menyajikan gambaran informasi atau deskripsi suatu data variabel dari suatu penelitian yang dilakukan dengan karakteristik data yang diperoleh untuk penyebaran kuisioner.

Tabel 1 Deskripsi Variabel

\begin{tabular}{|c|c|c|}
\hline Variabel & Definisi & Indikator \\
\hline $\begin{array}{l}\text { Pemanfaatan Media } \\
\text { Pembelajaran } \\
\text { Audiovisual } \\
\text { Sumber: (Ahmad } \\
\text { Rohani; Soendojo } \\
\text { Dirdjosoemarto; } \\
\text { Djamarah; Edgar Dale) }\end{array}$ & $\begin{array}{l}\text { Pemanfaatan media } \\
\text { pembejaran audiovisual } \\
\text { adalah pemanfaatan } \\
\text { media elektronik, suara, } \\
\text { gambar serta animasi }\end{array}$ & $\begin{array}{l}\text { - Pemanfaatan elektronik } \\
\text { - Suara } \\
\text { - Gambar } \\
\text { - Animasi }\end{array}$ \\
\hline $\begin{array}{l}\text { Motivasi } \\
\text { Sumber: (Dimyati \& } \\
\text { Mudjiono; Morgan; } \\
\text { Handoko; Arief S. } \\
\text { Sadiman; Hamalik; }\end{array}$ & $\begin{array}{l}\text { - Motivasi merupakan } \\
\text { suatu daya atau } \\
\text { kemampuan yang } \\
\text { mendorong seseorang } \\
\text { untuk melakukan } \\
\text { sesuatu }\end{array}$ & $\begin{array}{l}\text { - Tekun menghadapi tugas } \\
\text { - Ulet menghadapi kesulitan } \\
\text { - Tidak memerlukan dorongan } \\
\text { dari luar untuk berprestasi } \\
\text { - Ingin mendalami bahan atau } \\
\text { bidang pengetahuan yang }\end{array}$ \\
\hline
\end{tabular}




\begin{tabular}{|c|c|c|}
\hline Variabel & Definisi & Indikator \\
\hline $\begin{array}{l}\text { Djamarah; Lake; } \\
\text { Hamzah B. Uno; } \\
\text { Sardiman; Makmun; } \\
\text { Woolfolk; Slavin; } \\
\text { Dahar; Masri Kuadrat) }\end{array}$ & $\begin{array}{l}\text { - } \text { Motivasi positif akan } \\
\text { Memperlihatkan minat, } \\
\text { mempunyai perhatian } \\
\text { dan ingin tahu; } \\
\text { Bekerja keras, serta } \\
\text { memberikan waktu } \\
\text { kepada usaha tersebut, } \\
\text { dan terus bekerja } \\
\text { sampai tugas } \\
\text { terselesaikan } \\
\end{array}$ & $\begin{array}{l}\text { diberikan } \\
\text { - Selalu berusaha berprestasi } \\
\text { sebaik mungkin } \\
\text { - Menunjukkan minat terhadap } \\
\text { macam-macam masalah } \\
\text { - Senang dan rajin belajar, } \\
\text { penuh semangat, cepat bosan } \\
\text { dengan tugas-tugas rutin, } \\
\text { dapat mempertahankan } \\
\text { pendapatnya }\end{array}$ \\
\hline $\begin{array}{l}\text { Adversity Quotient } \\
\text { Sumber: (Stoltz; } \\
\text { Agustian; Ginanjar; } \\
\text { Sinamo; Garmezy dan } \\
\text { Michael; Greenberg; } \\
\text { Wangsadinata dan } \\
\text { Suprayitno) }\end{array}$ & $\begin{array}{l}\text { Adversity Quotient } \\
\text { merupakan suatu } \\
\text { kemampuan individu } \\
\text { untuk dapat bertahan } \\
\text { dalam menghadapi } \\
\text { segala macam kesulitan } \\
\text { sampai menemukan jalan } \\
\text { keluar, memecahkan } \\
\text { berbagai macam } \\
\text { permasalahan, mereduksi } \\
\text { hambatan dan rintangan } \\
\text { dengan mengubah cara } \\
\text { berfikir dan sikap } \\
\text { terhadap kesulitan } \\
\text { tersebut }\end{array}$ & $\begin{array}{lr}- & \text { Kendali/Control } \\
- & \text { Kepe } \\
- & \text { milikan/origin and ownership } \\
\text { auan/Reach } & \text { Jangk } \\
\text { lendurance } & \text { Tahan }\end{array}$ \\
\hline $\begin{array}{l}\text { Prestasi Belajar } \\
\text { Sumber: (Slamet; } \\
\text { Hamalik, Kamus Besar } \\
\text { Bahasa Indonesia; } \\
\text { Suryabrata; Arif } \\
\text { Wahyudi; Ni Ayu } \\
\text { Kusuma Wardani; } \\
\text { Arikunto; Hasbulah) }\end{array}$ & $\begin{array}{l}\text { Prestasi belajar adalah } \\
\text { hasil yang diperoleh dari } \\
\text { aktivitas tes dan } \\
\text { dilakukan pada saat } \\
\text { kondisi tertentu berupa } \\
\text { nilai }\end{array}$ & $\begin{array}{l}\text { - Nilai Tugas } \\
\text { - Nilai LKS } \\
\text { - Nilai Ulangan Harian }\end{array}$ \\
\hline
\end{tabular}

Penelitian ini dilakukan dengan menggunakan model SEM (Structural Equotion Modelling) yang terdiri atas measurement model dan structural model yang bertujuan untuk menguji apakah model tersebut fit dengan data yang ada dan analisis yang digunakan untuk menguji hipotesis dilakukan dengan AMOS. Ada empat variable yang diteliti yaitu variable bebas terdiri dari pemanfaatan media pembelajaran audiovisual, motivasi dan adversity quotient serta variabel terikat adalah prestasi belajar matematika. Untuk mempermudah memahami konsep penelitian ini, maka diharapkan rancangan desain penelitian ini dapat memberikan gambaran yang jelas.

Variabel yang diungkap dalam penelitian ini adalah hasil belajar, yaitu hasil belajar matematika siswa yang diajar dengan menggunakan media audiovisual dan hasil belajar matematika dengan media konvensional. Untuk memberikan gambaran yang jelas tentang variabel yang diteliti dalam penelitian dapat diberikan batasan sebagai berikut: a) hasil belajar matematika siswa yang diajar menggunakan media audiovisual adalah hasil yang 
diperoleh siswa dalam belajar matematika dengan menggunakan media audiovisual. Sedangkan b) hasil belajar matematika siswa adalah siswa yang diajar dengan menggunakan cara (media) konvensional adalah hasil yang diperoleh siswa dalam belajar matematika dengan menggunakan cara (metode) konvensional.

Populasi dalam penelitian ini adalah Siswa Kelas X yang berjumlah 147 (seratus empat puluh tujuh) orang. Tahun ajaran 2013/2014. kemudian diambil melalui teknik random sederhana (simpl2e random sampling). Dengan rincian kelompok A diambil dari kelas TKJ sebanyak 102 orang (yang diajar dengan menggunakan audiovisual) dan kelompok B dari kelas AP sebayak 45 orang (yang diajar dengan menggunakan konvensioanal).

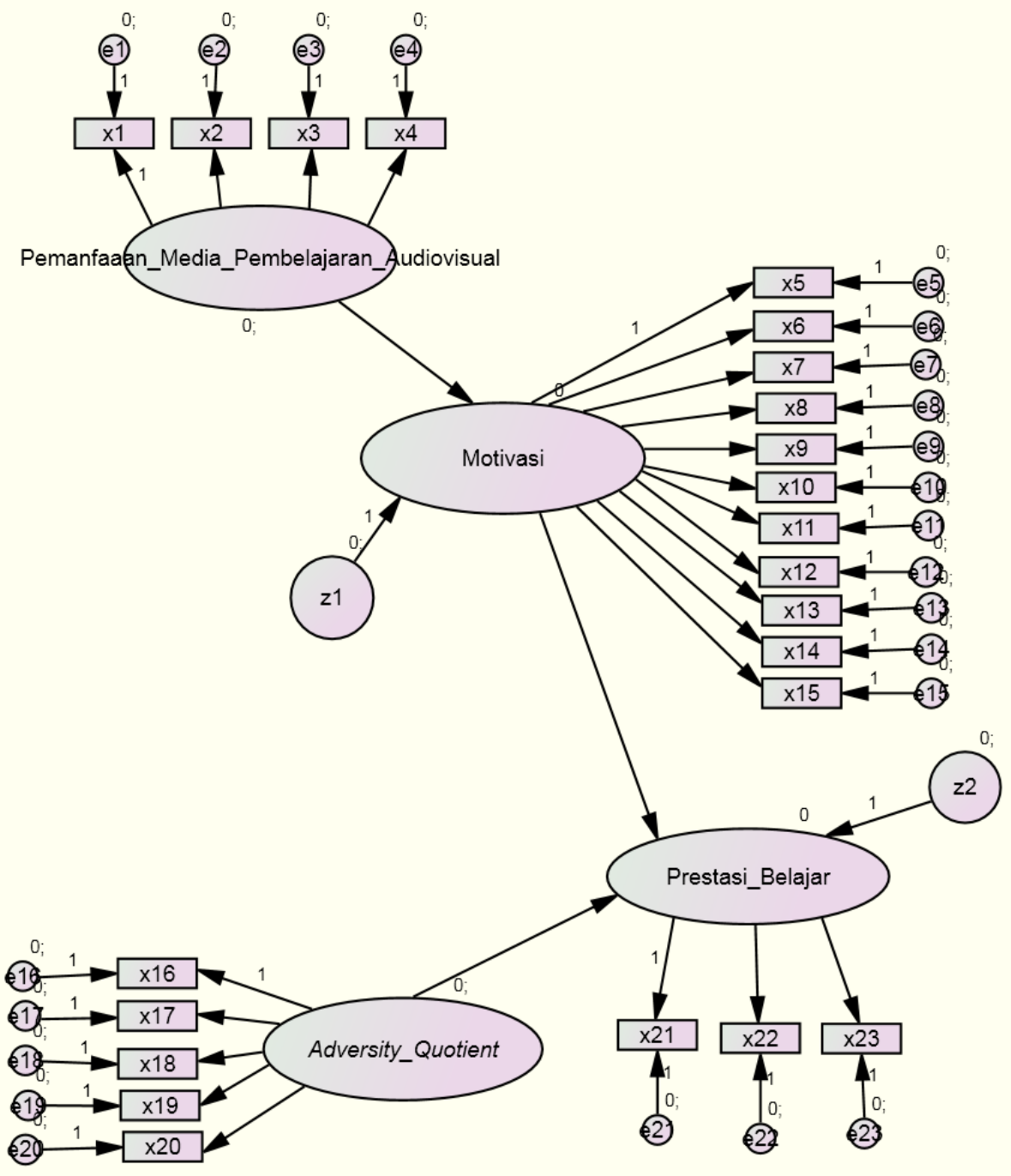

Gambar 1

Desain Penelitian

Instrumen dikembangkan berdasarkan silabus matematika dan dijabarkan mulai pokok bahasan sampai sub-pokok bahasan serta indikator-indikator yang akan dicapai. Pola pengembangan tes menggunakan model tes prestasi hasil belajar, dimana model soalnya menggunakan essay. Tes yang dilakukan hanya pada kondisi tertentu saja, hasilnya berupa nilai, yang terdiri nilai tugas, nilai LKS dan nilai ulangan harian. Untuk 
mengumpulkan data yang diperoleh dalam penelitian ini, menggunakan angket (kuisioner), observasi dan studi dokumentasi.

Teknik analisis untuk menguji variabel pertanyaan menggunakan Uji Validitas dan Reliabilitas dengan program SPSS ver 16.0, sedangkan untuk mengetahui seberapa tepat variabel-variabel manifes tersebut dapat menjelaskan variabel laten menggunakan Uji Validitas Measurement Model dan Uji Model Secara Keseluruhan (Overall Model Fit Test) serta Modifikasi Model SEM dengan AMOS ver 16.0.

\section{HASIL DAN PEMBAHASAN}

Deskripsi responden akan memberikan penjelasan tentang gambaran identitas responden. Dalam penelitian ini responden adalah siswa-siswa SMK Rosma kelas X TKJ (kelas eksperimen) dan AP (kelas kontrol) tahun 2013/2014 yang berjumlah seratus empat puluh tujuh siswa.

\subsection{ANALISIS DESKRIPTIF STATISTIK DATA}

Variabel yang digunakan dalam penelitian ini, yaitu pemanfaatan media pembelajaran audiovisual, motivasi, adversity quotient dan prestasi belajar siswa akan dianalisis secara deskriptif.

Analisis deskriptif dilakukan dengan menggunakan software SPSS 16. Bagian ini akan membahas bentuk sebaran jawaban responden terhadap keseluruhan konsep yang akan diukur. Dari sebaran jawaban responden tersebut, selanjutnya akan diperoleh sebuah kecenderungan dari seluruh jawaban yang ada. Kuisioner yang telah diisi oleh responden kemudian dikompilasi dan diolah mejadi data penelitian. Dari data yang diperoleh, diketahui bahwa jumlah data pada semua indikator lengkap sesuai dengan jumlah responden.

Untuk lebih jelasnya lagi, deskripsi variabel bertujuan untuk menyajikan gambaran informasi atau deskripsi suatu data variabel dari suatu penelitian yang dilakukan dengan karakteristik data yang diperoleh dari hasil penyebaran kuisioner. Untuk medapatkan kecenderungan jawaban responden terhadap jawaban masing-masing variabel akan didasarkan pada rentang skor jawaban sebagaimana pada lampiran. Jika dimasukkan dalam rentang kategori skor, rata-rata tersebut dapat dikategorikan sebagai berikut:

1) Skor minimal : 1

2) Skor maksimal : 5

3) Rentang skala : $\frac{5-1}{5}=0,8$

Adapun pengelompokkan hasil kuisioner terbagi dalam kategori:

1) $1,00-1,80 \quad:$ sangat rendah/sangat buruk

2) $1,81-2,60:$ rendah/buruk

3) $2,61-3,40 \quad:$ cukup/sedang

4) $3,41-4,20:$ tinggi/baik

5) $4,20-5,00 \quad:$ sangat tinggi/sangat baik

Berdasarkan hasil perhitungan dengan program SPSS ver 16.0 dapat disajikan pengujian validitas dengan hasil uji validitas yaitu valid untuk semua pertanyaan. Pengukuran keandalan butir pertanyaan dengan menyebarkan kuisioner pada responden, kemudian hasil skornya diukur korelasinya antarskor jawaban pada butir pertanyaan yang sama dengan bantuan SPSS, dengan fasilitas Cronbach Alpha (a). Suatu konstruk atau variabel dikatakan reliable jika memberikan nilai cronbach alpha >0,60.

Berdasarkan hasil perhitungan dengan program SPSS ver 16.0 dapat diketahui bahwa seluruh variabel koefisien alpha $>0,6$, sehingga seluruh pertanyaan dalam setiap 
variabel adalah reliabel, sehingga variabel-variabel yang ada layak digunakan sebagai variabel penelitian.

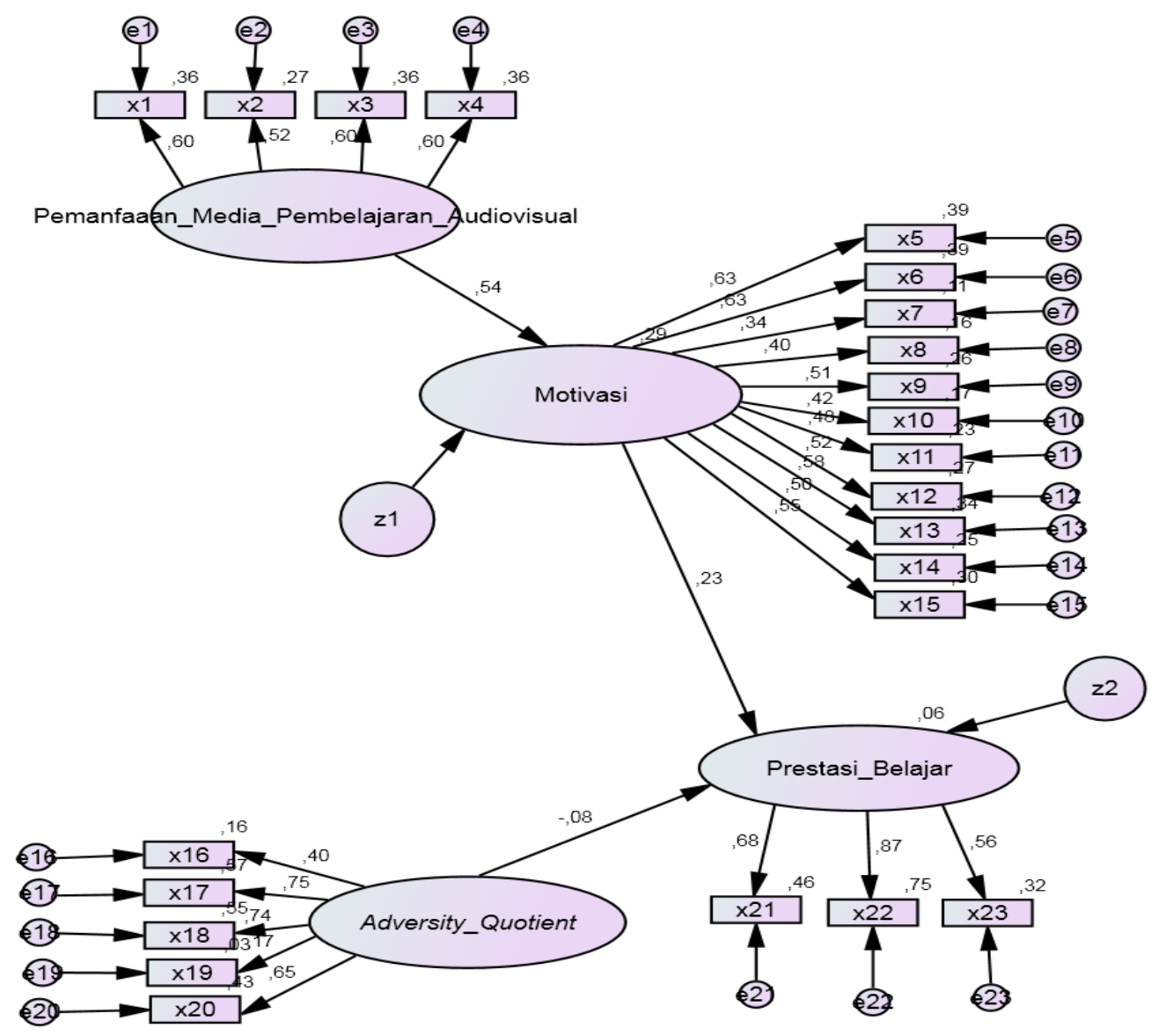

Gambar 2

Model SEM

Tabel 2 Uji Goodness of Fit

\begin{tabular}{|c|c|c|c|}
\hline Kriteria Kesesuaian Model & HASIL AMOS & Skala Penerimaan & Interpretasi \\
\hline Chi-Square (CMIN) & 462,869 & $\begin{array}{l}\text { Terletak diantara } \\
\text { saturated model dan } \\
\text { independence model }\end{array}$ & Kesesuain baik \\
\hline $\begin{array}{l}\text { RMSEA (RM error of } \\
\text { approximation) }\end{array}$ & ,084 & $\begin{array}{l}0 \text { (tidak fit) s/d } 1 \\
\text { (fit) }\end{array}$ & Kesesuain baik \\
\hline TLI (Tucker-Lewis Index) & ,676 & $\begin{array}{l}0 \text { (tidak fit) s/d } 1 \\
\text { (fit) }\end{array}$ & $\begin{array}{l}\text { Kesesuaian } \\
\text { Menengah }\end{array}$ \\
\hline NFI (Normed Fit Index) &, 565 & $\begin{array}{l}0 \text { (tidak fit) s/d } 1 \\
\text { (fit) }\end{array}$ & $\begin{array}{l}\text { Kesesuaian } \\
\text { Menengah }\end{array}$ \\
\hline CFI (Confirmatory Fit Index) & ,709 & $\begin{array}{l}0 \text { (tidak fit) s/d } 1 \\
\text { (fit) }\end{array}$ & $\begin{array}{l}\text { Kesesuaian } \\
\text { Menengah }\end{array}$ \\
\hline $\begin{array}{l}\text { PCFI (Parcimonius Fit } \\
\text { Index) }\end{array}$ & ,636 & $\begin{array}{l}0 \text { (tidak fit) s/d } 1 \\
\text { (fit) }\end{array}$ & $\begin{array}{l}\text { Kesesuaian } \\
\text { Menengah }\end{array}$ \\
\hline
\end{tabular}


Dengan demikian, hasil Chi-Square didukung oleh alat-alat statistik yang lain, sehingga dapat dikatakan model di atas telah fit.

\subsection{PEMBAHASAN HIPOTESIS}

Berdasarkan hasil pengujian hipotesis dapat diketahui bahwa pemanfaatan media pembelajaran audiovisual berpengaruh signifikan terhadap motivasi belajar siswa, sehingga hipotesis terbukti secara empiris dan diterima.

Hal ini terbukti berdasarkan tabel Regression Weights pada kolom $\mathrm{P}$ terlihat nilai $\mathrm{P}$ adalah ***, hal ini menunjukkan angka $\mathrm{P}$ adalah 0,000 yang jauh di bawah 0,05 . Karena itu $\mathrm{H}_{0}$ ditolak, jadi pengujian nilai Motivasi dengan Pemanfaatan Media Pembelajaran Audiovisual, dapat dikatakan ada hubungan yang nyata diantara keduanya.

Untuk motivasi belajar siswa tidak memiliki pengaruh signifikan terhadap prestasi belajar siswa, sehingga hipotesis ini tidak diterima. Hal ini berdasarkan tabel Regression Weights pada kolom $\mathrm{P}$ terlihat nilai $\mathrm{P}$ adalah 0,74 . Untuk tingkat signifikan $5 \% \mathrm{H}_{0}$ diterima, tapi jika menggunakan tingkat signifikan $1 \% \mathrm{H}_{0}$ ditolak. Tapi untuk nilai estimasi motivasi terhadap prestasi belajar bernilai positif, sesuai dengan tabel Standardized Regression Weights.

Sedangkan untuk adversity quotient siswa tidak memiliki pengaruh terhadap prestasi belajar siswa, sehingga hipotesis ini tidak diterima. Berdasarkan hasil pengamatan dari penulis, beberapa indikator yang dapat menyebabkan adversity quotient tidak memiliki pengaruh terhadap prestasi belajar siswa kelas X TKJ dan AP SMK Rosma tahun pelajaran 2013/2014, tidak bisa mengerjakan soal matematika.Hal tersebut berdasarkan tabel Regression Weights pada kolom $\mathrm{P}$ terlihat nilai $\mathrm{P}$ adalah 0,511 . Untuk tingkat signifikan $5 \% \mathrm{H}_{0}$ diterima, tapi jika menggunakan tingkat signifikan $1 \% \mathrm{H}_{0}$ ditolak. Untuk nilai estimasi pun bernilai negatif untuk adversity quotient terhadap prestasi belajar pada mata pelajaran matematika. Hal ini menunjukkan untuk mata pelajaran matematika faktor kegigihan tidak berpengaruh pada prestasi belajar siswa.

\section{KESIMPULAN DAN SARAN}

Penelitian ini menganalisa bagaimana pemanfaatan media pembelajaran audiovisual, motivasi dan adversity quotient terhadap variable independent prestasi belajar siswa SMK Rosma kelas X TKJ dan kelas X AP tahun pelajaran 2013/2014. 1). Setelah kegiatan pembelajaran dengan menggunakan pemanfaatan media pembelajaran audiovisual pada mata pelajaran matematika, motivasi siswa mengalami peningkatan. Hal ini menunjukkan pemanfaatan media pembelajaran audiovisual dapat meningkatkan motivasi belajar siswa pada mata pelajaran matematika berdasarkan hasil output AMOS. 2) Berdasarkan penelitian yang penulis lakukan, ternyata motivasi belajar siswa untuk tingkat signifikan 5\% tidak berpengaruh pada prestasi belajar siswa, karena pada tabel standardized regression weight pada kolom $\mathrm{P}$ bernilai 0.74 , tetapi estimate benilai positif untuk motivasi siswa terhadap prestasi belajar mata pelajaran matematika. 3). Adversity quotient tidak berpengaruh secara signifikan terhadap prestasi belajar siswa, terlihat dari tabel yang menunjukkan pada kolom $\mathrm{P}$ untuk adversity quotient memiliki nilai 0,511 dan untuk estimate juga bernilai negatif. Jadi tidak ada kegigihan siswa dalam mata pelajaran matematika terhadap prestasi belajar.

Berdasarkan dari hasil olah data dan pembahasan, penulis memberikan beberapa saran diantaranya untuk pihak sekolah hendaknya meningkatkan pemeliharaan media, seperti LCD, speaker sebagai penunjang kegiatan pembelajaran. Karena terbukti dengan pemanfaatan media pembelajaran audiovisual dapat meningkatkan moivasi belajar anak, khususnya pada mata pelajaran matematika. Penelitian kedepan hendaknya mengarah pada penelitian dengan objek yang lebih luas, misalnya dengan responden seluruh siswa SMK 
rosma Karawang, mengembangkan penelitian mengenai pemanfaatan media pembelajaran audiovisual secara khusus karena pengaruh audiovisual sangat besar terhadap motivasi belajar siswa. Serta menggali lebih lagi variabel-variabel lain yang dapat mempengaruhi prestasi belajar siswa.

\section{DAFTAR PUSTAKA}

Abdurrahman, Mulyono. Pendidikan Bagi Anak Berkesulitan Belajar. Rineka Cipta Jakarta. 2003

Agnew, P. W., Kellerman, S.S \& Meyer, M.J.. Multimedia in the classroom. Allyn and Bacon. Boston. 1996

Agustian, Ary Ginanjar. Rahasia Sukses Membangun Kecerdasan Emosi dan Spiritual ESQ: Emotional Quotient Berdasarkan Enam Rukun Iman dan Lima Rukun Islam. Arga. Jakarta. 2001

Albrecht, Simon L. and Andreetta, Manuela. The Influence Of Empowering Leadership, Empowerment And Engagement On Affective Commitment And Turnover Intentions In Community Health Services Workers. Leadership in Health Services, Vol. 24 No. 3, pp 228-237. 2011

Andriyana Yayan, Sri Hastuti Noer, Pentatito Gunowibowo. Pengaruh Pembelajaran Audiovisual Terhadap Pemahaman Konsep Matematika Siswa. Vol 1, No 9. 2013

Bayani, Irma dan Hafizhoh Nur. Hubungan Antara Adversity Quotient dan Dukungan Sosial Dengan Intensi Untuk Pulih dari Ketergantungan Narkotika Alkohol Psikotropika dan Zat Adiktif (NAPZA) Pada Penderita Di Wilayah Bekasi Utara Lembaga Kasih Indonesia. Jurnal Soul. 4 (2), 64-83. 2011

Bukhari, Tazeem Ali Shah dkk. The effects of psychological contract breach on various employee level outcomes: The moderating role of Islamic work ethic and adversity quotient. African Journal of Business Management. 5(21), 8393-8398. 2011

Cantrell, P., Liu, L. Leverington, M., \& Taylor, J., The effects of differentiated technology integration on student achievement in middle school science classrooms. International Journal of Technology in Teaching and Learning, 3(3), 36-54. 2007

Chasanah Nur Amalia. Modul: Pengenalan Program SPSS dan Amos. 2011

Haryoko, Sapto. Efektivitas Pemanfaatan Media Audio-Visual Sebagai Alternatif Optimalisasi Model Pembelajaran. Jurnal Edukasi@Elektro Vol. 5, No. 1, hlm 1 10. Maret 2009

Pratiwi, Bunga, Pramudiyanti \& Rini Rita T. Marpaung. Pengaruh Penggunaan Media Audio Visual Terhadap Aktivitas dan Hasil Belajar Siswa. Vol 1, No. 7.2013

Purwadilaga Dewi Salma. Prinsip Disain Pembelajaran Instructional Design Principles. Kencana Prenada Media Group. Jakarta. 2007

Rafiqah, Mar'atur, Yusmansyah Yusmansyah, Shinta Mayasari. Pengaruh Motivasi Belajar Siswa Terhadap Prestasi Belajar Siswa. Vol 2, No 2. 2013

Widodo, Joko dan Ellyana, Novita Eka. Pengaruh Pengembangan Motivasi dan penggunaan Fasilitas Belajar di SekolahTerhadap Prestasi Belajar Pada Mata Pelajaran Ekonomi. Jurnal Pendidikan Ekonomi, vol 5. No.2. Universitas Negeri Jember. Jember. 2011

Wlodkowski, Raymond J. Motivasi Belajar. Cerdas Pustaka. Depok. 2004 
Zakaria, Effandi and Norazah Mohd Nordin. The Effects of Mathematics Anxiety on Matriculation Students as Related to Motivation and Achievement. Eurasia Journal Mathematics, Science \& Technology Education. Vol 4 No. 1. 2008 